\title{
STRATÉGIAI ÉS KÖRNYEZETI ZAJTÉRKÉPEZÉS SZEREPE A MÚSZAKI FELSŐOKTATÁSBAN
}

\section{THE ROLE OF STRATEGIC AND ENVIRONMENTAL NOISE MAPPING IN TECHNICAL EDUCATION}

\author{
Kocsis Dénes ${ }^{1}$, Bertalan Nikolett ${ }^{2}$, Fórián Sándor ${ }^{3}$ \\ ${ }^{I}$ Debreceni Egyetem Müszaki Kar Környezet- és Vegyészmérnöki Tanszék; 4028 \\ Magyarország, Debrecen, Ótemetö utca 2-4; Telefon: +3652/415155-7781; \\ kocsis.denes@eng.unideb.hu \\ ${ }^{2}$ Debreceni Egyetem, Müszaki Kar, Környezet- és Vegyészmérnöki Tanszék, 4028 \\ Magyarország, Debrecen, Ótemetö utca 2-4; nikibertalan@gmail.com \\ ${ }^{3}$ Debreceni Egyetem, Müszaki Kar, Környezet- és Vegyészmérnöki Tanszék, 4028 \\ Magyarország, Debrecen, Ótemető utca 2-4; forian@eng.unideb.hu
}

\begin{abstract}
In our work we intend to investigate the role of strategic and environmental noise mapping in technical education. General information on noise mapping including the legislative requirements and the associated Hungarian practice is reviewed. In addition through the example of our institution the University of Debrecen the role of the topic in educational and scientific activities is presented, furthermore the results of a related project are also discussed.
\end{abstract}

Keywords: noise, noise mapping, technical education.

\section{Összefoglalás}

Munkánk során a stratégiai és környezeti zajtérképezés műszaki felsőoktatásban betöltött szerepét kívánjuk vizsgálni. Áttekintjük a zajtérképezéssel kapcsolatos ide tartozó általános tudnivalókat, többek között a jogszabályi követelményeit és magyarországi gyakorlatát. Emellett intézményünk a Debreceni Egyetem példáján keresztül bemutatjuk témakör szerepét az oktatási és tudományos tevékenységekben, továbbá kitérünk a területhez kapcsolódó egy projekt keretében folytatott tevékenység eredményeire is.

Kulcsszavak: zaj, zajtérképezés, müszaki felsőoktatás.

\section{Bevezetés}

A zajtérképezés a közelmúltban és napjainkban egy dinamikusan fejlődő terület, ami egyre inkább élvezi nem csak a politikai döntéshozók, hanem a közvélemény növekvő figyelmét is. A jelenlegi számítógépes háttér már lehetővé teszi nagy földrajzi kiterjedésü területeken is az alkalmazhatóságát, ezért egyre szélesebb körü alkalmazása figyelhető meg elsősorban az Európai Unióban, de a világ más részein is. A megnövekedett figyelem növekvő ipari és közigazgatási igényekkel is párosul, mely szükségessé teszi az ilyen irányú ismeretekkel rendelkező hallgatók képzését. Ennek megfelelöen a zajtérképezés megjelent a müszaki 
felsőoktatásban hallgatói és oktatói tudományos munkák keretében, valamint emellett speciális tárgyak is foglalkoznak a témakör ismereteinek átadásával. Ehhez kapcsolódóan munkánkban át kívánjuk tekinteni a zajtérképezés szerepét a müszaki felsőoktatásban.

\section{Stratégiai zajtérképezés}

A stratégiai zajtérkép egy terület meglévő vagy elöre jelzett zajhelyzetére vonatkozó adatok illusztrációja. A meghatározásból is látható, hogy jelenlegi viszonyok felmérésén és bemutatásán túl, alkalmas lehet tervváltozatok eredményeként bekövetkező jövőbeli szituációk ábrázolására is. A stratégiai zajtérkép célja a környezeti zajok okozta káros hatások felmérése, csökkentése és elkerülése.

Megjelenésében és elterjedésében nagyon fontos szerepet kapott az Európai Unió 2002/49/EK irányelve (2002/49/EK irányelv a környezeti zaj értékeléséről és kezeléséről), amely egységes keretek közé emelte a környezeti zaj értékelését és kezelését. Az angolul The Environmental Noise Directive irányelvet kezdőbetüiből END megnevezéssel szokták emlegetni. Ez a direktíva célozta meg a közös megközelítés kidolgozását a környezeti zajból eredő káros hatások elkerülésére, megelőzésére és csökkentésére. Ezen cél elérése érdekében számos lépés fokozatos megvalósítását tủzték ki, valamint alapot szolgáltattak a legjelentősebb zajforrásokból származó nemkívánatos zajterhelés csökkentésére. A források között az irányelv kiemelte a közúti és vasúti jármüveket és infrastruktúrákat, a légi közlekedést, és a szabadtéri és ipari berendezés zaját. A lefektetett általános irányelvek hasonlóak az egyéb területek (pl. levegö, vagy hulladék) átfogó környezeti politikájához.

\subsection{2/49/EK irányelv által bevezetett zajindikátorok}

$\mathrm{Az}$ irányelv az egységes értelmezhetőség és kezelhetőség érdekében zajindikátorokat határoz meg. Ezek közül a folyamatos zajterhelés nagyságának meghatározására alkották meg az ún. nappal-este-éjjel zajszint fogalmát [1]. Ez az irányelvben $\mathrm{L}_{\mathrm{den}}-\mathrm{ként}$ szerepel, amelyben a den index az angol megfelelő rövidítéséböl származik (day-eveningnight).

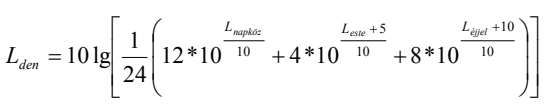

$\mathrm{L}_{\text {napköz }}, \mathrm{L}_{\text {este, }}$, és $\mathrm{L}_{\text {éjjel }} \mathrm{A}$-súlyozószürővel meghatározott hosszúidejü $L_{\text {Aeq }}$ érték. A definíció alapján nappali időszak 12 órásnak (reggel 7 órától 19 óráig), az esti 4 órásnak (19 órától 23 óráig), valamint az éjszakai 8 órásnak (23 órától reggel 7 óráig) tekintendő. A tagországok ettől saját szokásaik, hagyományaik alapján kis mértékben eltérhetnek [2]. Ennek megfelelően Magyarországon a 6-18-22 órás (6 órától napköz, 18 órától este és 22 órától éjszaka) tagolás használatos [3].

A-direktíva külön kitér azokra a mérési feltételekre, amelyek alapján a napszakok átlagos hangszintjét meg lehet állapítani. Ez alapján a zajtérképezést épületek között a terepszinttől $4 \pm 0,2 \quad \mathrm{~m}$ magasan kell elvégezni, lehetőleg a zajnak leginkább kitett felületnél [2]. Alacsonyabban is van lehetőség méréseket elvégezni minimum 1,5 méteres magasságig, de az eredményeket minden esetben 4 méterre korrigálni szükséges.

A környezeti zajtérkép készítés is ugyanazon jogi és müszaki szabályokra támaszkodik, csak jóval kevesebb kötöttséggel. Környezeti zajtérképezés esetén számos paramétert a zajtérképezési feladathoz szokás igazítani. 


\subsection{Magyarországi törvényi szabályozás}

A magyarországi jogszabályi háttérbe való illeszkedése a stratégiai zajtérképeknek a következő jogszabályokkal történt meg [3]:

- Az 1995. évi LIII. a környezet védelmének általános szabályairól szóló törvény és annak a 2004. évi LXXVI. törvénnyel történő módosítása;

- 280/2004. (X. 20.) Korm. rendelet a környezeti zaj értékeléséről és kezeléséről;

- 25/2004. (XII. 20.) KvVM rendelet a stratégiai zajtérképek, valamint az intézkedési tervek készítésének részletes szabályairól.

A 280/2004. (X. 20.) Korm. rendelet határidőket is megszab, mely alapján Budapest stratégiai zajtérképének 2008. július 18-ig, a 100000 fönél nagyobb lakosú magyarországi városok stratégiai zajtérképének pedig 2012. június 30-ig kellett elkészülniük. A zajtérképezés eredményeként felmért zajállapotot a rendelet által meghatározott úgynevezett küszöbértékekkel kell összevetni. Az összevetés eredménye határozza meg, hogy az adott terültre milyen tartalmú intézkedési tervet kell készíteni és azt milyen időtávon belül kell megvalósítani.

A stratégiai zajtérképeken zajforráscsoportonként, valamint zajjellemzőkként is el kell készíteni a térképes megjelenítést, ahol $5 \mathrm{~dB}$-es lépésközü, különböző színnel jelölt zajszintgörbéket kell alkalmazni [4]. A konfliktustérképeken jelennek meg a küszöbérték túllépések, melyeket szintén különböző színű, 5 dB-es vagy annál nagyobb felbontású zajszintgörbék megadásával kell ábrázolni [5]. Továbbá táblázatos formában meg kell adni az érintett lakosság számát és az érintett lakóépületek, iskolák és kórházak számát is a konfliktustérképen.

\section{Stratégiai és környezeti zajtérképezés az oktatásban}

$\mathrm{Az}$ említett növekvő piaci igények eredményeképpen a zajtérképezés témakör az utóbbi időben egyre hangsúlyosabban jelentkezik a müszaki felsőoktatásban. Ezt nagyon jól mutatja a témában készült hallgatói tudományos diákköri munkák, szakdolgozatok és diplomamunkák száma. Emellett a témakör megjelenik az oktatók és kutatók kutatási tevékenységében is.

A terület fontos szerepet kap intézményünk a Debreceni Egyetem Müszaki Karának oktatási tevékenységében is. Itt elsősorban Környezetmérnöki BSc és MSc szakos hallgatók foglalkoznak a témakörrel. A szakon nagy hagyománya van a zaj- és rezgésvédelmi témakörök oktatásának, ennek megfelelően hallgatók több féléven keresztül hallgatnak egymáshoz kapcsolódó Zaj- és rezgésvédelem tárgyakat. Ezen tárgyak közül az egyik (Zaj- és rezgésvédelem III) teljes egészében a zajtérképezéssel kapcsolatos ismeretek átadására törekszik. Ennek keretében a hallgatók megismerik és elsajátítják egy zajtérkép-készítő szoftver használatát, és tudásukról elektronikus zárthelyi és önálló zajtérképezési feladat megoldásával adnak számot. A később ilyen szakterületen elhelyezkedett hallgatók visszajelzései alapján a piac pozitívan értékeli az ilyen jellegú ismereteiket.

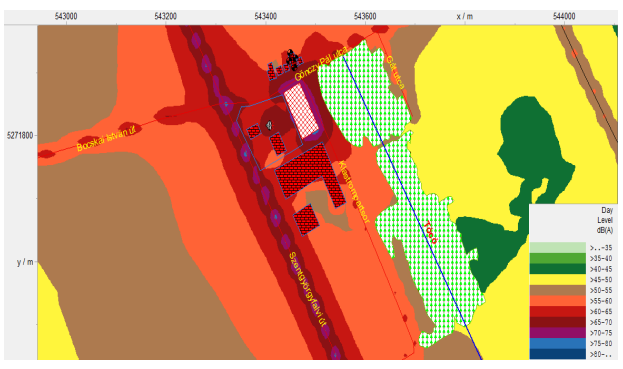

1. ábra. Környezetmérnöki BSc szakos hallgató által elektronikus zárthelyi megoldásaként készitett feladat 
Jelen publikáció készítői részben érintettek voltak a TÁMOP 4.1.1.C2012/1/KONV-2012-0012 Zöld Energia Felsőoktatási Együttmüködés (ZENFE) címü projektben, mely során többek között egy zajtérképezési mintaadatbázist létrehozásában tevékenykedtek. Ezen munka során készült egy webes felület, ami általános információkat tartalmaz nemcsak a hallgatók, hanem minden érdeklődő számára is a zajtérképekről. A felületen szerepelnek továbbá az elkészült magyarországi zajtérképek elérhetőségei, valamint külföldi példák is helyet kaptak.

A nemzetközi kitekintés jól felhívja arra a véleményünk szerint közeljövőben orvosolandó problémára a figyelmet, hogy míg például Anglia területének jó része esetében egyazon felületröl ugyanolyan formában megtekinthetőek különböző térségek zajtérképei, addig sajnos a magyarországi gyakorlat ezt nem teszi lehetővé. Hazánkban a zajtérképek jellemzően a városok honlapjain, egymástól elszigetelten jelennek meg, melyek egységes kezelése jelentősen növelné azok értékét.

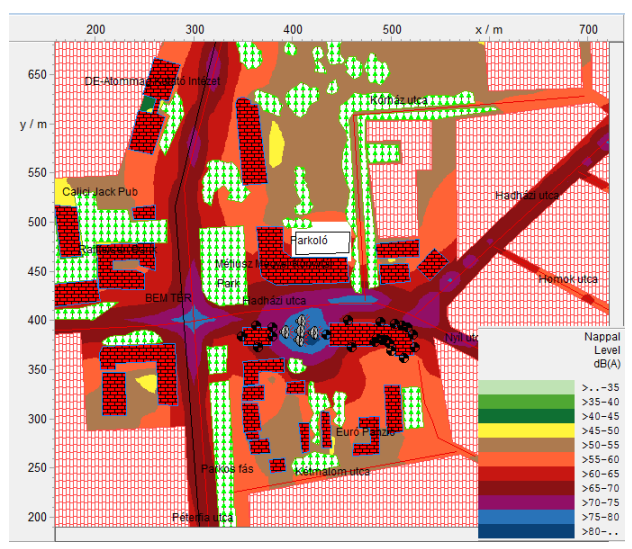

2. ábra. Környezetmérnöki BSc szakos hallgató által gyakorlati jegy megszerzéséhez készitett önálló beadandó feladat

\section{Következtetések}

Írásunkban a stratégiai és ahhoz kapcsolódóan a környezeti zajtérképezés témakörét tekintettük át. Célunk a terület müszaki felsőoktatásban betöltött szerepének a vizsgálata volt. Saját intézményünk, a Debreceni Egyetem példáján keresztül bemutattuk a témakör megjelenését a különböző tudományos munkákban és az oktatásban. Emellett a területhez kapcsolódóan egy projekt keretében végzett munka eredményeibe is rövid betekintést adtunk.

\section{Szakirodalmi hivatkozások}

[1] Kiss Ádám, Tasnádi Péter: Környezetfizika, Typotex, Budapest, 2012, 138.

[2] Position paper on EU noise indicators, Office for Official Publications of the European Communities, Belgium, 2000, 10.

[3] Berndt Mihály: Részletes háttér-információ a környezeti zaj értékeléséröl és kezeléséröl szóló 280/2004. Korm. rendelet végrehajtásához, Budapest, 2007, pp. 7.

[4] Domokos Endre (szerk.): Környezetmérnöki Tudástár, 13. kötet, Zaj- és rezgésvédelem, Veszprém, 2011, 142.

[5] European Commission Working Group Assessment of Exposure to Noise (WG-AEN): Position Paper, Good Practice Guide for Strategic Noise Mapping and the Production of Associated Data on Noise Exposure, Version 2, August 2007, 43. 